\title{
Methodology for the collection and application of information on food habits and food preferences in menu planning of heterogeneous groups
}

\author{
Annemarie Viljoen \& Gerda Gericke
}

\begin{abstract}
OPSOMMING
In die literatuur oor spyskaartbeplanning word daar dikwels verwys na die belangrikheid om oorweging aan kliëntfaktore (eetgewoontes en voedselvoorkeure) te skenk. Inligting oor die metodes om hierdie inligting te bekom, is goed gedokumenteer. Geen inligting word egter in die literatuur gerapporteer oor hoe die versamelde inligting oor eetgewoontes en voedselvoorkeure in die praktyk in spyskaartbeplanning aangewend kan word nie.

In hierdie artikel word die metodologie wat toegepas is vir die bepaling van die eetgewoontes en voedselvoorkeure van sewe verskillende etniese groepe dienspligtiges, soos verteenwoordig in die Suid-Afrikaanse Weermag gedurende 1993 tot en met Maart 1994, gerapporteer. Die verwerking van, asook aanbevelings vir die praktiese gebruik van hierdie empiriese voorkeurinligting in spyskaartbeplanning word uitgelig.
\end{abstract}

\section{- Mrs AT Viljoen}

Department of Home Economics

University of Pretoria

\section{- Ms GJ Gericke}

Division of Human Nutrition

University of Pretoria

* Based on an M Dietetics thesis under the supervision of Ms GJ Gericke

\section{INTRODUCTION}

It is the responsibility of the management of a food service unit to determine the needs and expectations of the clients of the service, and to try to satisfy these needs by planning and producing appropriate menus (Sullivan, 1990:107; Spears, 1995:161).

A thorough knowledge of the food habits of the client group for which menus are planned is important, and it becomes of the utmost importance when the group is heterogeneous. Although some institutions consist of homogenous groups, the majority of institutional populations such as found in schools, universities and the Defence Force, generally reflect the heterogeneity of a society (Eckstein, 1983:15).

Knowledge of the food habits and the food preferences of the client group is essential to enable the menu planner to:

- evaluate existing menus (If the menus do not match the clients' food habits and food preferences, the necessary adjustments should be made.)

- evaluate the probable acceptance of new items on the menu

- ensure that when menus are planned for heterogeneous client groups, the diverse food habits of the different groups are accommodated.

According to Spears (1995:161), the menu planner should take both client satisfaction and management decisions into consideration when menus are planned. These two factors should always be considered concurrently.

The importance of considering client-related factors as well as the methods that may be used to acquire information on the food habits and food preferences of clients is well documented (Meiselman \& Waterman, 1978; Eckstein, 1983:15-17; Puckett \& Miller, 1988:199; Baltzer \& Gilmore, 1992:187; Spears, 1995:161-164). Meiselman (1979:151) mentioned that procedures on using the acquired food preference information in menu planning should be investigated, and emphasised the importance of having objective data on food preferences available when menus are planned. No information could, however, be found in the literature (over the past twenty years) on how the collected information on food habits and food preferences should be used in menu planning.

\section{Aims of the article}

The first aim was to report how information was obtained on the habitual eating patterns and food preferences of the male members (16-25 years) of the South African population who participated in military training in the South African Defence Force (SADF) during 1993 up to March 1994. The second aim was to illustrate how these results on food habits and preferences could be applied as practical recommendations in menu planning for heterogeneous groups.

RESEARCH PERSPECTIVE 
The South African population is heterogeneous and comprises a variety of ethnic groups, including whites, coloureds and different black ethnic groups. The origins, development and cultures of these groups differ, and the food habits and food preferences of these groups are also different.

The field of study of food habits and food preferences is complex and diverse (Gibson, 1981; Sanjur, 1982:25; Kuhnlein, 1989; Parraga, 1990), and a thorough analysis and comprehension of all the human activities involved in the use of food is required to study food habits and food preferences (Peryam, 1963; Sims, 1978; Randall \& Sanjur, 1981; Khan, 1981; Sanjur, 1982; Krondl, 1990). An individual's food habits is the result of the joint interaction of external and internal environmental factors (Sims \& Smiciklas-Wright, 1978; Sims, 1978; Parraga, 1990).

The model illustrated in Figure 1 represents the factors that influence the formation of habitual eating patterns. It also indicates where the acquired information on habitual eating patterns and food preferences should be applied when menus are planned for institutions.

\section{Description of key concepts}

External environment refers to the man-made environment which determines the availability of food for human consumption (as a result of technological developments in food processing, storage and distribution). The external environment also represents the sociocultural factors that determine what food will be chosen.

Internal environment refers to the unique characteristics of the individual that influence food habits and food preferences. These characteristics include biological and physiological characteristics as well as endogenous characteristics of knowledge, attitudes, values and beliefs.

Food habits are practices and associated attitudes that predetermine the way in which individuals or groups of individuals select, consume, and utilise portions of the available and preferred food in response to social and cultural pressures (Mead, 1945:13; Eckstein, 1983:15). The habitual eating pattern of an individual is an integral part of his or her food habits (see description of habitual eating patterns).

Food preference may be described as the degree of like or dislike of a particular food. Food preference therefore indicates an individual's personal motivation to choose from the available, acceptable food. Food preference is clearly a phenomenon that rests predominantly in the affective domain and exists independently of consumption (Randall \& Sanjur,1981). Various factors contribute to the individual's motivation to prefer a specific food. These factors may be divided as follows:

- Characteristics of the food
- Characteristics of the individual

- Characteristics of the environment

(Khan, 1981; Randall \& Sanjur, 1981)

Frequency of food consumption indicates how often an individual consumes or intends to consume a specific food item during a predetermined period (day, week, month).

Habitual eating pattern is the recurrent pattern in which an individual chooses, prepares and consumes food from the available, acceptable food for a specific meal or snack. This eating pattern includes the specific combination of foods that are used as a meal or a snack as well as the distribution of the meals and snacks through the day. Habitual eating pattern therefore describes the meal composition and meal distribution of an individual or a group. (Snack refers to food and/or beverages that are consumed between meals.)

Client factors are factors that relate directly to the client group in menu planning, such as nutritional requirements, meal patterns, food preferences and the frequency of food consumption.

Management factors are factors in food service systems management that have to be considered in menu planning, such as the available human resources, the food budget, and the food service unit's available facilities and production capabilities.

\section{METHOD}

\section{Questionnaire}

A questionnaire was compiled to elicit information regarding food habits. This questionnaire was divided into different sections, namely a section on demographic information, a section on the habitual eating pattern and a section on food preferences.

Demographic information Closed and openended questions were used to obtain demographic information about the participants. The ethnic groups to which participants belonged, were determined by including a question on home language. This was considered necessary to categorise the sample into subgroups for the comparison of food habits of different ethnic groups.

Habitual eating pattern In this section the habitual eating patterns (outside the SADF) of the participants were determined by means of closed questions on the composition of meals and meal patterns. The composition of meals was determined by asking the participants to indicate which food items, from a given list, were usually (3-4 times per week) consumed for a specific meal. The number of meals eaten as well as when these meals were eaten was determined. The difference in eating patterns over weekends and during weekdays (if applicable) was established, and foods that were bought as snacks were identified. 


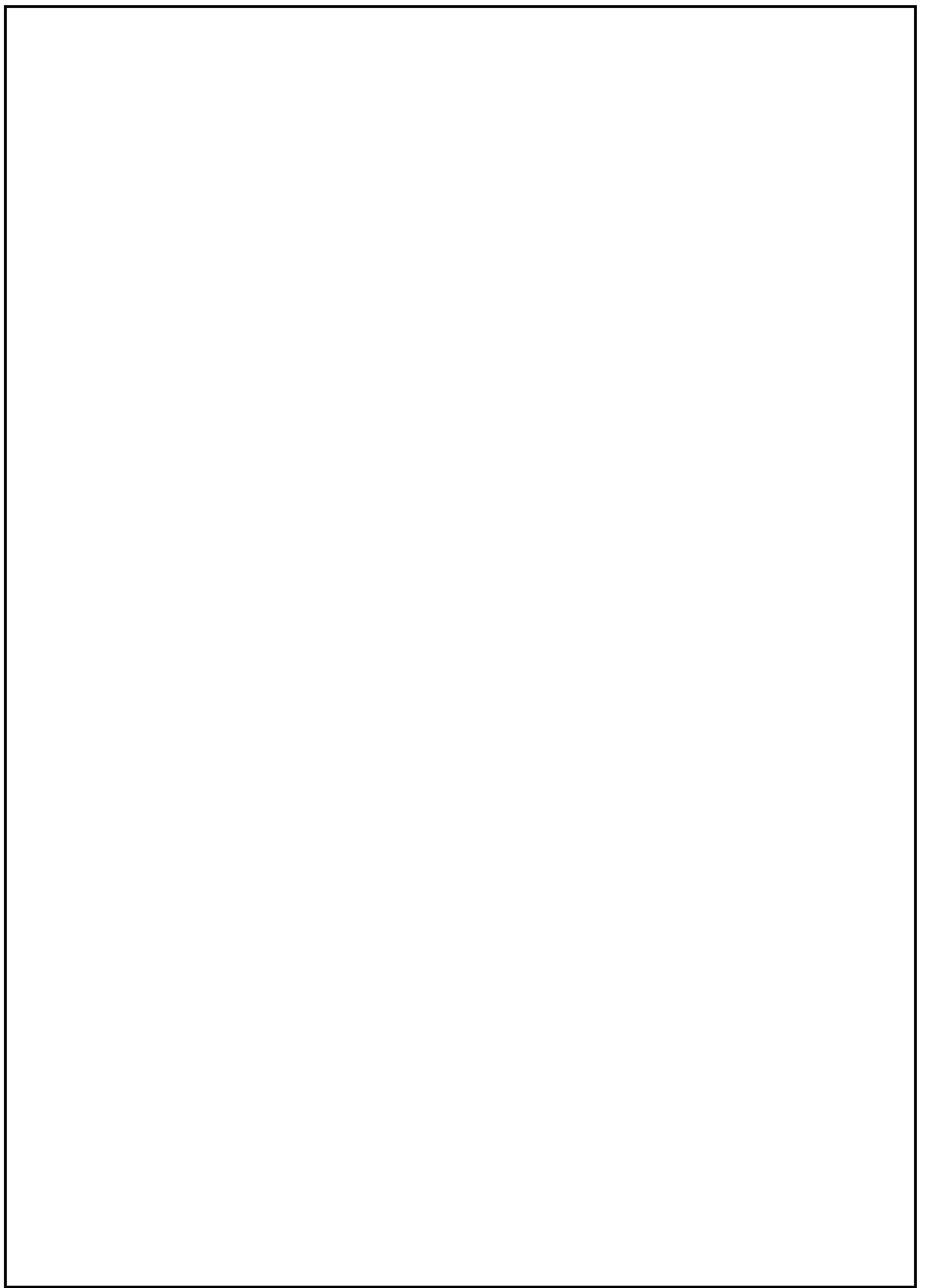

FIGURE 1: $\quad$ THE FACTORS THAT INFLUENCE THE FORMATION OF HABITUAL EATING PATTERNS 
The information gathered on habitual eating patterns helped to identify the eating patterns (composition and distribution of meals) of the different ethnic groups.

Food preference A food preference questionnaire was developed to determine familiarity with food items, food preferences and the intended frequency of use. A list of 219 food items was compiled. The 219 food items (typically served in the SA Army at the time of this study was done (1993-1994)) and the grouping of these items as reported by Meiselman \& Waterman (1978) were used as a basis for compiling the list of food items in this section. The Scale 1 ration scale (of food items), as used by the SADF, was used to check the initial list to ensure that all items, as indicated on the ration scale, were included in the questionnaire. The 219 food items were grouped in the following categories in view of the menu planning process:

\author{
- Protein-rich items: 69 items \\ - Starches: 31 items \\ - Vegetables: 54 items \\ - Fruit: 17 items \\ - Desserts: 13 items \\ - Breakfast cereals: 10 items \\ - Bread and bread products: 12 items \\ - Beverages: 13 items.
}

Familiarity was defined as whether the participant knew the food, and was judged in terms of known, not known, not sure what it was. If the food item was familiar, the participant had to indicate whether he had ever eaten the item. The questionnaire was structured to determine familiarity with each food item, after which a preference rating was determined. Preference ratings were therefore conducted for familiar foods only.

Food preference was defined as the degree of like or dislike of a food (Randall, 1982:124; Rozin \& Vollmecke, 1986) and was rated on a seven-point hedonic scale ranging from like extremely (scale value 7) to dislike extremely (scale value 1).

Intended frequency of use was defined as the intended action related to the acceptable frequency of use of a food item and was measured by the Food Action Rating Scale (FACT scale). Intended frequency was indicated by the number of days out of 30 days on which the participant would be willing to eat the particular food item. The two measuring scales (preference rating scale and FACT scale) were used simultaneously. The FACT scale was an additional instrument which together with the hedonic scale determined the total preference for each food item (Schutz, 1965).

Pretesting The preliminary questionnaire was tested on 100 servicemen of the Technical Services Training Centre (Voortrekkerhoogte). It took approximately 60 minutes for the servicemen to complete the questionnaire. They encountered no problems in completing the questionnaire and the questionnaire was therefore regarded as easy to read and not too difficult to fill in.
Validity The questionnaire was checked for internal and external validity. Theoretical validity was ensured by a thorough study of the literature on the theories of food habits and food preferences. Measurement validity was ensured by judging the questionnaire for content validity and construct validity. A checklist was compiled to ensure that all the relevant aspects were measured. The section for marketing research of the Human Sciences Research Council (HSRC) judged the questionnaire for readability, clarity and comprehension. External validity was supported by the sample size of this project $(\mathrm{N}=1088)$, but was hampered by the sampling technique.

Reliability The questionnaire was tested beforehand for reliability by using the test-retest technique (Babbie, 1989:122; Bailey,1987:72). Eighteen servicemen of different ethnic groups were requested to fill in the questionnaire after it was tested by the HSRC, and were again asked to do so after a period of two weeks. The results of these two sets of questionnaires were compared and only $5(1,04 \%)$ of the total of 483 variables measured by the questionnaire $(P=0,05)$ differed significantly after the two-week lapse. The questionnaire was consequently regarded as reliable to measure food habits and food preferences.

\section{Sample}

Selection and description During the previous dispensation, white male South Africans were called up for military service from 16 years of age, and men in the same age group from the other ethnic groups could join the army voluntarily. On average the age during which military service was performed varied between the ages of 16 and 25 years. The population therefore consisted of male members of the SADF between the ages of 16 and 25 years who performed military service during 1993 up to March 1994, and who had been in the South African Army for no longer than six months. A minimum qualification of Standard 8 as well as bilingualism (Afrikaans and English) were set as inclusion criteria. A time limit was set in order to ensure that the habitual eating pattern could be recalled. It was assumed that the service men's food habits could change while they were in the SADF and were exposed to unfamiliar foods and peer group pressure.
Sampling Convenience sampling was used. A subsample size of $n=150$ was initially set for each ethnic group represented in the South African Army during the time of the study. However, after the for- mation of the Government of National Unity in May 1994, the structure of the South African Army changed so that the different ethnic groups were no longer in separate units. It was therefore logistically impossible to find servicemen in the different ethnic groups where the subsample size of $n=150$ was not met. It was therefore decided to use only the data collected up to March 1994 (1 172 questionnaires). The sample consequently consisted of the seven 
most representative ethnic groups in the South African Army during 1993 until March 1994. Special care was taken to ensure that the sample size of each ethnic group made the applicable statistical processing possible.

\section{Data collection and analysis}

Data collection In cooperation with the Catering Corps of the South African Army, various units and training battalions were visited. An officer of the $\mathrm{Ca}$ tering Corps arranged and escorted the researcher on these visits. It was requested that the participants should be available for a period of two hours to complete the questionnaires which were available in Afrikaans and English. Instructions were given by the researcher. The various units provided officers who were available to assist the researcher and to act as interpreters if necessary. On completion, each questionnaire was checked for completeness and the participants were requested to complete the unanswered questions. Missing information was thus restricted to the minimum.

Analysis of data The coding of the data was done by the researcher. The SAS computer program, version 6 (1988), was used for the data analysis. Frequency ratings (expressed as percentages) were calculated for the data on demographics, habitual eating patterns and meal composition. For the food preference and frequency of intended usage, the following method was used for each of the 219 food items (menu items and dishes):

- Variables were not normal at the $5 \%$ level (test Shapiro-Wilk, 1965). In view of the risk of using a global calculating method to compare the variables, this was not done (O'Mahoney, 1986:366).

- Median and mode values were calculated.

- The values on food preferences and intended frequency of use were used to rate each food item as either a high (median value of 5-7), neutral (median value of 4-4,99) or a low (median value of 1-3,99) preference item. (This was done separately for each of the seven ethnic groups.)

To facilitate the interpretation and the discussion of the results obtained on the preference ratings and to give an indication of the popularity of each food item, the following arbitrary criteria were used for ranking the food items:

- Low preference item Any item with a median value of 1-3,99 was ranked as a low preference item (these were items the participants did not like).

- Neutral preference item Any item with a median value of 4- 4,99 was ranked as a neutral preference item.

- High preference item Any item with a median value of 5-7 was ranked as a high preference item.
Along with the preference evaluation, the intended frequency of use was determined for each of the 219 food items. To ease the discussion and to indicate the popularity of each item, the indicated frequency of use was presented in the following manner:

- $\quad$ Never (0 days)

- Sometimes (1-3 out of 30 days)

- $\quad$ Often (4-10 out of 30 days)

- Twice a week (11-30 out of days).

The rating score, measured familiarity and intended frequency of use of the food items as such were evaluated concurrently (see Table 1 , example on savoury mince). The foods to be included versus excluded in the menu planning were identified in this manner for each ethnic group.

The food items were regrouped into the five basic food groups (according to kind within a food group) and ranked according to the preference ratings to help the menu planner to make the most appropriate choice (taking nutritional value and preference into account) when selecting foods for menus.

The items for each kind of food was ranked by numerical value. Asterisks $\left(^{*}\right)$ were used to indicate whether a food was a high $\left({ }^{* *}\right)$, neutral $\left({ }^{* *}\right)$ or low $\left(^{*}\right)$ preference item (see Table 2 for the example on the preference ranking of pork dishes).

To accommodate the recommendations on the prudent diet, additional symbols were used within the different food groups to indicate which foods were high in specific nutrients or ingredients (salt and sugar and/or good sources of dietary fibre).

The following symbols were used:

* Foods that are good sources of dietary fibre. These are foods that contain $\geq 2 \mathrm{~g}$ of dietary fibre (Whitney et al, 1990:97).

- Foods that are exceptionally high in fat. These are foods that contain $\geq 15 \mathrm{~g}$ fat per $100 \mathrm{~g}$ portion (Whitney et al, 1990:31).

Foods that are high in sugar, referring to sugar added during processing.

- Foods that are high in salt, referring to salt added during processing.

Foods that are high in calcium.

Sweet and sour pork: ranked lowest by all ethnic groups (position 7) and a low $\left(^{*}\right)$ or neutral $\left({ }^{* *}\right)$ preference food item.

\section{Description of sample}

The sample is described in Table 3.

\section{RESULTS}

Habitual eating patterns 
TABLE 1: $\quad$ FOOD PREFERENCES AND INTENDED FREQUENCY OF USE OF PARTICIPANTS ( $N=1$ 088) FOR SAVOURY MINCE

The results with respect to the habitual eating pattern indicated that the whites and coloureds followed the so-called Western eating pattern. (See Table 4 for the habitual eating pattern.) Similar results were reported by Langenhoven et al (1988) and Walker (1992). This eating pattern is characterised by the consumption of three meals per day with regular snacks between meals, and a weekend meal pattern that differs from the weekday meal pattern. In contrast to the traditional eating pattern where two meals were consumed on week and weekend days, it was found that the black groups consumed three meals per day and that the eating pattern on weekend days differed in terms of the size of the different meals.

Although the black groups indicated maize meal porridge as a food item that was regularly consumed at all three meals of the day, bread and rice were also reported to be included in certain meals as a starch together with maize porridge. (See Table 5 for foods habitually consumed.) Bread was frequently consumed at breakfast and lunch, and rice was included at lunch and supper. With the exception of the Northern Sothos, all the other ethnic groups indicated that potatoes and vegetables or salads were usually (3-4 times per week) included at lunch and supper. The Northern Sothos indicated that only porridge and meat were consumed for lunch and supper. Based on these results the Northern Sotho group (of which $69,9 \%$ grew up in the rural areas of the former Northern Transvaal) was still following the more traditional meal composition of porridge and meat or a relish. Crous \& Borchardt (1982) found that the Pedi families in Atteridgeville (Pretoria) were still following the traditional meal composed of maize porridge and a relish.

Milk was traditionally part of the daily diet of the black ethnic groups, although it was consumed as sour milk. The respondents in this study indicated that fresh milk, fruit juices, Coca-Cola and coffee were popular beverages and were usually (3-4 times per week ) consumed between meals.

Familiarity, food preference and frequency of use

The results indicated that the majority of the participants from all the ethnic groups were familiar with the food items listed in the questionnaire and had eaten the items before. The results on familiarity as such, preference for the item and the intended frequency of use were compiled for each food item per ethnic group (see Table 1 for an example).

Application of data on habitual eating habits, food preference and frequency of use in menu planning 
TABLE 2

PREFERENCE RANKING OF PORK DISHES

TABLE 3: $\quad$ DESCRIPTION OF SAMPLE $(\mathbf{N}=1088)$

Recommendations with regard to menu planning were made to the South African Army, based on the data obtained with respect to habitual eating patterns, food preferences and intended frequency of use. The prescribed criteria for menu planning followed by the South African Army (H Leër/D Spys/302/6dd 23 Maart 1992) were also taken into consideration. The recommendations concerning the meal plans are discussed first, followed by the recommendations for menu item choices.

Recommendations for adjustments to meal plans

The daily menus in the South African Army were planned according to the meal plans given Table 6 .

Items that were included in the habitual eating pattern of $\geq 40 \%$ of the participants were used as criteria for 


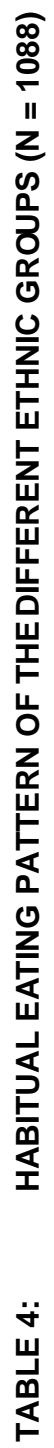

Methodology for the collection and application of information on food habits and food preferences in menu planning of heterogeneous groups 


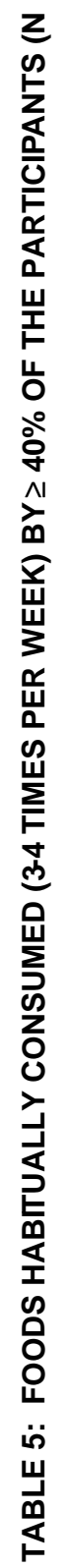

Methodology for the collection and application of information on food habits and food preferences in menu planning of heterogeneous groups 
making the following recommendations with regard to meal plans. (See Table 7.) It was assumed that if $\geq$ $40 \%$ of the participants consumed a menu item for a particular meal, that item was representative of the eating pattern of a particular ethnic group.

The results of the foods usually (3-4 times per week) eaten by the participants for lunch, indicate that the above-mentioned meal plan is similar to the meal plan identified for lunch by most of the ethnic groups in this study. The eating pattern of the whites and that of the Northern Sothos were however different from those of the other ethnic groups. These two groups indicated that a smaller variety of food items was consumed at lunch.

The results show that supper was usually (3-4 times per week) eaten and that the given meal plan corresponded with the eating patterns of all the ethnic groups in this study, except the Northern Sothos. According to $\geq 40 \%$ of the Northern Sothos only porridge and meat were consumed for supper.

It is recommended that the meal plan that is currently used for supper be maintained. It is recommended that a choice of starch dishes should be available for lunch at least every second day.

\section{Recommendations for menu item choices}

Food preferences Although the food preference information may be used as an index of consumption, the intended frequency of use of a food item should not be ignored when the popularity of the item is determined. When the intended frequency of use is used as an additional aid to determine the popularity of an item, it should however be kept in mind that no perfect relationship exists between the preference for and the frequency of selection of a food item. Monotony could be a determining factor.

According to Eckstein (1983:21), studies indicated the following:

- Some foods with a high preference will be chosen often, for example milk, fruit juice, toast, eggs, ap- ples and bacon. Because the preference is high, these items are not likely to become monotonous when used frequently.

- Some items that individuals like will be chosen less frequently, for example steak, chicken and french fries. These items are prone to monotony which overrides preference.

- It has also been found that some items that are not liked will be chosen more often, for example coffee, tea and mixed salad. These items are not prone to monotony and preference therefore becomes less critical (Eckstein, 1983:22).

Another problem with frequency ratings is that the intended frequency of use might appear exceptionally high (Meiselman,1979:139) because the participants were not asked to plan menus, but to indicate, item by item, how often they would use an item. The results of the intended frequency of use should therefore be seen as an additional instrument in determining food preferences in order to prevent menu fatigue. (In this study the intended frequency of use was compared with the preference rating of each of the food items (see Table 1)).

Nutritional value Client-related factors (preference ratings and intended frequency of use as well as nutritional value) should be addressed simultaneously to enable the menu planner to make the most appropriate food choices when planning menus for a particular group or groups. It was therefore decided to regroup the 219 food items into the five basic food groups and to rank the items in each food group according to the preference ratings. By doing this the criteria for menu planning as prescribed by the South African Army (use of the five basic food groups) were adhered to. At the same time the acquired preference information was made available in a format that could be used with ease in menu planning.

Food preference information In each of the five basic food groups the different menu items were presented by grouping them into "kinds". "Kind" is defined as a category set up on the basis of a common characteristic, for example baby marrow and hubbard

TABLE 6: DAILY MEAL PLANS USED IN THE SOUTH AFRICAN ARMY

\begin{tabular}{|l|l|l|}
\hline BREAKFAST & LUNCH & SUPPER \\
Fruit juice & Protein-rich dish & Protein-rich dish \\
Porridge/Breakfast cereal & Gravy & Gravy \\
Protein-rich dish 1/(Egg is served & Starch & Starch \\
daily) & Vegetable 1 & Vegetable 1 \\
Protein-rich dish 2 & Vegetable 2/Salad & Vegetable 2/Salad \\
Bacon (served daily) & Bread with margarine and spread & Bread with margarine and spread \\
Bread with margarine and spread & Dessert & Fresh fruit \\
Coffee & Milk & Tea/Coffee \\
& Coffee/Tea & \\
\hline
\end{tabular}


squash are kinds of vegetables that belong to the pumpkin family, whereas hamburgers, savoury mince and fricadels are kinds of meat dishes prepared with minced meat. The menu items within a kind category were ranked and the ranking was indicated by a numerical value in combination with asterisks. Asterisks were used to indicate whether a food was a high $\left({ }^{* * *}\right)$, neutral $\left({ }^{* *}\right)$ or low $\left({ }^{*}\right)$ preference item. The lowest value according to the numerical ranking indicated the highest preference. Table 8 presents the preference ranking for the kinds of pork dishes.

In the coloured group the participants indicated that ham and bacon were high preference items $\left({ }^{* * *}\right)$, and leg of pork, fried pork chops, crumbed pork chops and pork sausage $\left({ }^{* *}\right)$ were rated as neutral items. Sweet and sour pork was rated a low $\left(^{*}\right)$ preference item. Although leg of pork, fried pork chops, crumbed pork chops and pork sausage were all rated as neutral items, they could be ranked. Of these neutral items, fried pork chops had the highest ranking $\left(3^{* *}\right)$, followed by pork sausage $\left(4^{* \star}\right)$, leg of pork $\left(5^{\star *}\right)$ and crumbed pork chops $\left(6^{\star *}\right)$.

The regrouping of the food items (as used in the questionnaire) into the five basic food groups resulted in the shifting of certain items to other groups and this influenced their numerical ranking. In these cases only the preference value $\left(^{*}\right)$ was indicated. For example, the milk and dairy products table is compiled from different subgroups in the questionnaire and therefore the original ranking could no longer be used. Fresh fruit was not ranked because most fruits were rated as high preference items. Fresh fruit is seasonal, and it was assumed that fresh fruit in season would be planned on the menus.

Prudent diet In the guidelines for a prudent diet, recommendations were made to increase or restrict the intake of certain foods. To enable the menu planner to accommodate these recommendations during menu planning, symbols were used to indicate which foods were high in specific nutrients or ingredients (salt and sugar) and/or good sources of dietary fibre. Some items in Table 9 are high in fat $(\cdot)$ and sugar ( ). These items should be used in moderation to ensure that the guidelines are met for a reduced fat intake and a moderate consumption of sugar. The use of low-fat dairy products should, for example, be considered.

Similar tables were compiled for three of the other food groups, namely for meat and meat substitutes, vegetables and fruit, and cereal products. A separate table was compiled to list the preference ratings for desserts and beverages because this information could contribute to menu planning for all the ethnic groups.

\section{Other aspects to consider when using the infor-} mation on food habits and food preferences

When the results of this study are implemented, the following should be kept in mind with regard to the use and application of the information:

Familiarity It is recommended that the food items marked as unknown and never eaten should not be categorically excluded when menus are planned. It should not be ruled out that the male participants were not familiar with the names of some of the dishes, and therefore marked them as unknown or never eaten. The unknown items should therefore first be introduced to the clients. This may be done by offering an unknown item as a choice on the menu and the client could subsequently be asked for a preference evaluation of the item. Only after this evaluation, should a decision be taken about the inclusion or exclusion of the item on the menu. It should also be established why certain items were marked as never eaten. Is it because of a taboo, or was the item not available or not affordable to the clients?

Food preferences The following have to be considered when the preference information is used:

- The food preferences were rated without considering the affordability, availability or obtainability of the items. Items that are often used should not be assumed to be high preference items. Some items might be consumed regularly because of their availability and affordability and the preference rating of these items could be neutral or even low. Although organ meat was purchased and consumed regularly by the black ethnic groups (compare Crous \& Borchardt, 1982, 1984), the preference rating for this group of items was neutral and low.

- The menu planner has to weigh preference information against other factors such as affordability (budget restrictions) for the South African Army as well as the availability and obtainability of the items.

- Food preferences are not static, and change over time. It is recommended that a survey of the food habits and food preferences of the different ethnic groups should be repeated from time to time to monitor any change(s) and to adapt the menus accordingly to ensure that the offered menus remain acceptable (Eckstein, 1983:17; Puckett \& Miller, 1988:200).

Intended frequency of use Information on the intended with caution, as explained earlier.

Captive consumer The clients of institutionalised food services are generally regarded as captive consumers, because these individuals do not have ready access to alternative means of obtaining meals (Shugart \& Molt, 1993:696). Captive consumers may be divided into two groups, i.e. short-term (hospital patients) and long-term (servicemen) consumers. More care should be given to planning menus for the latter group, for variety and frequency in the offered menu items that would prevent monotony.

Monotony in the offered food is a psychological construct which describes the dissatisfaction that could 
TABLE 7: RECOMMENDED MEAL PLAN CHANGES

\begin{tabular}{|c|c|}
\hline Existing SADF meal plan & Recommended changes \\
\hline \multicolumn{2}{|l|}{ BREAKFAST } \\
\hline Fruit juice & Omitted or served less frequently \\
\hline Porridge/Breakfast cereal & No change \\
\hline Protein-rich dish (eggs daily) & Reconsider daily serving of eggs. Eggs and cheese may be served alternately \\
\hline Bacon (daily) & Reconsider daily serving. Choice with eggs for whites. \\
\hline Bread with margarine and spread & No change \\
\hline Coffee & No change \\
\hline \multicolumn{2}{|l|}{ LUNCH } \\
\hline Protein-rich dish & No change \\
\hline Gravy & No change \\
\hline Starch & $\begin{array}{l}\text { Serve stiff maize porridge on alternate days for black ethnic groups. This rec- } \\
\text { ommendation has implications for the type of meat dish served with the por- } \\
\text { ridge. If a stewed type of meat dish is not planned, a gravy or vegetable relish } \\
\text { should be provided. }\end{array}$ \\
\hline Vegetable 1 & No change \\
\hline Vegetable 2/Salad & No change \\
\hline Bread with margarine and spread & No change \\
\hline Dessert & $\begin{array}{l}\text { Serve only twice per week. Include yoghurt and/or fresh fruit on days when } \\
\text { dessert is not served. Implementation of this recommendation will improve the } \\
\text { nutritional adequacy of the menus. }\end{array}$ \\
\hline Milk & No change \\
\hline Coffee/Tea & No change \\
\hline \multicolumn{2}{|l|}{ SUPPER } \\
\hline Protein-rich dish & No change \\
\hline Starch & No change \\
\hline Vegetable 1 & No change \\
\hline Vegetable 2/Salad & No change \\
\hline Bread with margarine and spread & No change \\
\hline Fresh fruit & No change \\
\hline Coffee/Tea & No change \\
\hline
\end{tabular}




\section{TABLE 8: $\quad$ PREFERENCE RANKING FOR KINDS OF PORK DISHES}

TABLE 9: $\quad$ PREFERENCES OF DIFFERENT ETHNIC GROUPS FOR MILK AND DAIRY PRODUCTS $(\mathrm{N}=1088)$

result because of the cyclic repetition of food items or even the repetition of colour, texture and shape of dishes (Eckstein, 1983:24). If the preference information is used without considering these aspects, there is a risk of planning monotonous menus. Guidelines should be followed to prevent the cyclic repetition of food items and to check for a variety of items and dishes on the menu. The interval between the serving of items and dishes as well as the length of the cycle menu should be checked. Items with a high or neutral preference rating could be served more often and at shorter intervals. The general rule seems to be that items with a lower preference rating have to be served after a longer time interval. If an item is absolutely unacceptable to a particular group, the time interval would be infinite and the item should not be planned on the menu (Eckstein, 1983:26).

\section{SUMMARY AND RECOMMENDATIONS}

The quantitive methodology that was used to obtain information on the food habits and food preferences of servicemen from seven different ethnic groups in the South African Army was explained. Recommendations were submitted on how the acquired information could be implemented in menu planning.

In view of similarities in the food habits and food preferences that are representative of the typical Western eating pattern, the whites and coloureds could be 
grouped together. On the other hand, the five black ethnic groups, who reported a Western-type of eating pattern but in combination with a traditional pattern, could be grouped together. Compared to the traditional ways, the meal patterns and food preferences of the black ethnic groups revealed certain tendencies indicating that the eating patterns of these groups were changing, probably due to acculturation.

It is recommended that the reported preference information be used to plan menus for the different ethnic groups who participated in this study. The acceptability of and the satisfaction of the clients with the planned menus should then be determined by means of opinion polls and/or plate waste studies. It would then be possible to determine whether the proposed method of applying preference information in menu planning would ensure acceptable menus.

\section{AKNOWLEDGEMENTS}

The authors wish to thank:

- Armscor for financing this research project

- Captain Corlia Prinsloo of the Catering Corps of the South African Army for her much appreciated assistance with the data collection

- Mrs Ansie Blignaut of Armscor for her valuable assistance with the data analysis.

\section{LITERATURE LIST}

BABBIE, E (1989): The practice of social research. 5th ed. Belmont. California. Wadsworth.

BAILEY, KD (1987): Methods of social research. 3rd ed. New York. Macmillan.

BALTZER, LE \& GILMORE, SA (1992): Food preparation study course. Quantity food preparation and scientific principles. 3rd ed. Ames. lowa State University Press.

CROUS, JM \& BORCHARDT, S (1982): Eetgewoontes van Pedi-huisgesinne in Atteridgeville. Tydskr Dieetkd Huishoudkd 10(1):29-31.

CROUS, JM \& BORCHARDT, S (1984): Dieetpatrone van Venda-gesinne in Atteridgeville. Tydskr Dieetkd Huishoudkd 12(2):41-44.

ECKSTEIN, EF (1983): Menu planning. 3rd ed. Westport, Connecticut. AVI.

GIBSON, LD (1981): The psychology of food: why we eat what we eat when we eat it. Food Technol 35(Feb):54-56. H LEËR/D Spys/302/6 dd 23 Maart 1992.

KHAN, MA (1981): Evaluation of food selection patterns and preferences. CRC Crit Rev Food Sci Nutr 17(Oct):129153.

KRONDL, M (1990): Conceptual models, in Anderson, GH. Diet and behavior: multidisciplinary approaches. London. Springer-Verlag.

KUHNLEIN, HV (1989): Culture and ecology in dietetics and nutrition. J Am Diet Assoc 89 (8):1059-1060.
LANGENHOVEN, ML, WOLMARANS, P, GROENEWALD, G, RICHTER, MJC \& VAN ECK, M (1988): Nutrient intakes and food and meal patterns in three South African population groups. Front Gastr Res 14:41-48.

MEAD, M (1964): Food habits research: problems of the 1960 's. Publication 1225. Washington. National Research Council.

MEISELMAN, HL (1979): Determining consumer preferences in institutional food service, in Livingston, GE \& Chang, CM. Food service systems. New York. Academic Press.

MEISELMAN, HL \& WATERMAN, D (1978): Food preferences of enlisted personnel in the armed forces. J Am Diet Assoc 73(12):621-629.

O'MAHONEY, M (1986): Sensory evluation of food. Statistical methods and procedures. New York. Dekker.

PARRAGA, IM (1990): Determinants of food consumption.

J Am Diet Assoc 90 (5):661-663.

PERYAM, DR (1963): The acceptance of novel foods.

Food Technol 17(June):33-39.

PUCKETT, RB \& MILLER, BB (1988): Food service manual for health care institutions. Chicago. American Hospital Publishers.

RANDALL, E \& SANJUR, D (1981): Food preferences their conceptualization and relationship to consumption. Ecol Food Nutr 11:151-161.

RANDALL, E (1982): Food preference as a determinant of food behavior in Sanjur, D. Social and cultural perspectives in nutrition. Englewood Cliffs. Prentice Hall.

ROZIN, P \& VOLLMECKE, TA (1986): Food likes and dislike. Ann Rev Nutr 6:433-456.

ROZIN, $P$ (1990): Acquisition of stable food preferences. Nutr Rev 48(2):106-113.

SANJUR, D \& SCOMA, AD (1971): Food habits of lowincome children in Northern New York. J Nutr Educ Winter:85-95.

SANJUR, D (1982): Social and cultural perspectives in nutrition. Englewood Cliffs. Prentice Hall.

SAS USER'S GUIDE (1988): Statistics. Ver 6. North Carolina. SAS Institute Inc.

SCHUGART, G \& MOLT, M (1993): Food for fifty. 9th ed. New York. Macmillan.

SCHUTZ, HG (1965): A food action rating scale for measuring food acceptance. J Food Sci 30:365-374.

SHAPIRO, SS \& WILK, MB (1965): An analysis of variance test for normality. Biometrika 52:591-611.

SIMS, LS, PAOLUCCI, B \& MORRIS, P (1972): A theoretical model for the study of nutritional status. Ecol Food Nutr 1:197-205.

SIMS, LS (1978): Food-related value-orientations, attitudes, and beliefs of vegetarians and non-vegetarians Ecol Food Nutr 7:23-35.

SIMS, LS \& SMICIKLAS-WRIGHT, H (1978): An ecological systems perspective: its application to nutrition policy, program design and evaluation. Ecol Food Nutr 7:173179.

SPEARS, MC (1995): Foodservice organizations: A managerial and systems approach. 3rd ed. New York. Prentice Hall.

SULLIVAN, CF (1990): Management of medical foodservice. 2nd ed. New York. Van Nostrand Reinhold.

WALKER, ARP (1992): Trends of nutritional intake patterns of South African interethnic populations. Cont Med Educ 10(8):1395-1403.

WHITNEY, EN, HAMILTON, EVN \& ROLFES, SR (1990): Understanding nutrition. 5 th ed. New York. West. 